DOI: https://doi.org/10.24127/ajpm.v10i3.4082

\title{
BERPIKIR KRITIS CALON GURU DALAM MENYELESAIKAN MASALAH KONTROVERSIAL MATEMATIKA DENGAN MENGGUNAKAN HIGH ORDER THINKING SKILLS
}

\author{
Alfiani Athma Putri Rosyadi ${ }^{1}$, Cholis Sa'dijah ${ }^{2 *}$, Susiswo $^{3}$, Swasono Rahardjo ${ }^{4}$ \\ ${ }^{1}$ Universitas Muhammadiyah Malang, Malang, Indonesia \\ ${ }^{1,2 *}, 3,4$ Universitas Negeri Malang, Malang, Indonesia \\ ${ }^{*}$ Corresponding Author. Jl. Semarang 5, 65145, Malang, Indonesia. \\ E-mail: alfi_rosyadi@umm.ac.id ${ }^{l)}$ \\ cholis.sadijah.fmipa@um.ac.id ${ }^{2 *}$ \\ susiswo.fmipa@um.ac.id ${ }^{3)}$ \\ swasono.rahardjo.fmipa@um.ac.id ${ }^{4)}$
}

Received 02 August 2021; Received in revised form 16 November 2021; Accepted 15 December 2021

\begin{abstract}
Abstrak
Penelitian ini bertujuan untuk mendeskripsikan proses berpikir kritis calon guru dalam menyelesaikan masalah kontroversial matematika dengan menggunakan High Order Thinking Skills. Penelitian ini menggunakan jenis penelitian studi kasus dengan pendekatan kualitatif. Subjek penelitian dalam penelitian ini adalah calon guru yang mengalami kontroversial setelah menyelesaikan masalah kontroversial yang diberikan. Instrumen penelitian yang digunakan adalah tes dan wawancara. Teknik analisis data yang digunakan adalah reduksi data, penyajian data dan penarikan kesimpulan. Proses berpikir dalam menyelesaikan masalah kontroversial matematika terdiri dari aspek identifying, connecting, applying, argumentation dan clarifying. Pada saat menggunakan HOTS untuk mengetahui proses berpikir kritisnya diperoleh kesimpulan bahwa tahap analisis terjadi pada saat calon guru identifying dan connecting. Untuk aspek evaluasi terjadi pada saat calon guru melakukan proses applying. Untuk aspek mencipta, terjadi pada saat calon guru menggunakan argumentation and clarifying dalam menyelesaikan masalah yang diberikan.
\end{abstract}

Kata kunci: Berpikir kritis; calon guru matematika; high order thinking skills; masalah kontroversial.

\begin{abstract}
This study aims to describe the critical thinking process of prospective teachers in solving controversial mathematics problems using High Order Thinking Skills. This research uses a case study research type with a qualitative approach. The research subjects in this study were prospective teachers who experienced controversy after solving a given controversial problem. The research instruments used were tests and interviews. The data analysis technique used is data reduction, data presentation and conclusion drawing. The thinking process in solving controversial mathematical problems consists of identifying, connecting, applying, argumentation and clarifying aspects. When using HOTS to determine the critical thinking process, it can be concluded that the analysis stage occurs when the prospective teacher is identifying and connecting. For the evaluation aspect, it occurs when the prospective teacher does the applying process. For the creative aspect, it occurs when prospective teachers use argumentation and clarifying in solving the problems given.
\end{abstract}

Keywords: Critical Thinking; Mathematics Prospective Teacher; High Order Thinking Skills; Controversial Issues.

This is an open access article under the Creative Commons Attribution 4.0 International License

\section{PENDAHULUAN}

Berpikir kritis adalah suatu kemampuan untuk melakukan proses berpikir secara sistematis dan dapat memahami keterkaitan antar ide. .Berpikir kritis penting dalam 
kehidupan sehari-hari dan perlu diberikan kepada calon guru (Serin, 2013; Ab Kadir, 2017; Basri et al., 2019). Berpikir kritis dapat membantu calon guru dalam menyelesaikan masalah yang diberikan. Selain itu berpikir kritis juga menjadi salah satu dari empat kemampuan yang ada dalam menghadapi abad 21 (Davies \& Barnett, 2015; Dwi Susandi et al., 2019; Smith et al., 2018).

Pentingnya berpikir kritis pada calon guru ini yang menyebabkan banyaknya penelitian yang mengangkat tentang berpikir kritis. Penelitian As'ari et al., (2017) menyebutkan bahwa calon guru matematika di Indonesia belum menjadi pemikir kritis. Saran penelitian tersebut adalah diperlukan praktik instruksional yang dapat digunakan untuk meningkatkan keterampilan berpikir kritis. Penelitian Susandi et al., (2018) menyebutkan bahwa calon guru masih memiliki kesalahan dalam menyelesaikan masalah keterampilan berpikir kritis. Karena pentingnya berpikir kritis calon guru dan berdasarkan hasil penelitian sebelumnya tentang calon guru belum menjadi pemikir kritis maka diperlukan penelitian lanjutan yang mengkaji tentang berpikir kritis calon guru.

Kemampuan berpikir kritis calon guru dapat muncul pada saat diberikan masalah yang di dalamnya terdapat dua hasil yang saling bertentangan (Nugroho et al., 2018). Lebih lanjut, penelitian Nugroho et al., (2018) menyebutkan bahwa penyebab calon guru melakukan refleksi agar menghasilkan kesimpulan yang benar dalam pengambilan keputusan adalah adanya konflik kognitif dan adanya dua hasil yang saling bertentangan. Munculnya konflik kognitif dapat terjadi setelah dihadapkan dengan masalah kontroversial. Masalah kontroversial adalah salah satu masalah yang dapat memunculkan konflik kognitif dan menyebabkan perbedaan pendapat ( Mueller \& Yankelewitz, 2014; Simic-Muller et al., 2015;Goldberg \& Savenije, 2018; Kello, 2016).

Penelitian tentang masalah kontroversial sudah dilakukan oleh Mueller \& Yankelewitz, (2014) dan menyebutkan bahwa dalam msalah kontroversial terdapat argumen yang tidak valid dan memunculkan beragam penalaran pada calon guru. Penelitian Simic-Muller et al., (2015) menyebutkan bahwa jarang sekali calon guru menyelesaikan masalah kontroversial dan peneliti juga memberikan rekomendasi untuk penelitian berikutnya agar memberikan masalah kontroversial dalam program pendidikan calon guru.

Berbagai penelitian yang membahas tentang masalah kontroversial sudah dilakukan tetapi belum ada yang mengaitkan dengan proses berpikir kritis, padahal menurut Mueller \& Yankelewitz, (2014) menyebutkan bahwa pada saat menyelesaikan masalah kontroversial muncul proses berpikir kritis calon guru.

Melihat proses berpikir calon guru dalam menyelesaikan masalah kontroversial dapat menggunakan beberapa jenis teori, misalkan APOS, Kognitif dan sebagainya (Ayvaz et al., 2016; Susandi et al., 2018; Dwi Susandi et al., 2019). Tetapi belum ada penelitian yang menggunakan High Order Thinking Skills (HOTS) dalam melihat proses berpikir kritis, padahal tahapan yang ada pada HOTS yaitu analisis dan evaluasi berkaitan dengan aspek yang ada pada berpikir kritis.

Penelitian tentang masalah kontroversial sudah dilakukan oleh beberapa penelitian sebelumnya yaitu (Rosyadi, 2021), tetapi belum dikaitkan 
dengan HOTS. Selain itu hasil penelitian tersebut menyebutkan bahwa diperlukan penelitian lanjutan yang mengkaji permasalahan kontroversial secara mendalam.

Berdasarkan permasalahan di atas, penelitian ini bertujuan untuk mengetahui proses berpikir kritis calon guru dalam menyelesaikan masalah kontroversial matematika dengan menggunakan High Order Thinking Skills (HOTS). Harapannya penelitian ini dapat dijadikan alternatif untuk peneliti lain dalam mengembangkan proses berpikir kritis.

\section{METODE PENELITIAN}

Pendekatan penelitian yang digunakan adalah pendekatan deskriptif yang didalamnya terdapat proses eksplorasi, melakukan kajian masalah dan melakukan proses pengembangan secara mendalam. Penelitian yang dilaksanakan adalah penelitian kualitatif dengan strategi studi kasus.

Subjek penelitian ini adalah calon guru yang mengalami kontroversial setelah menyelesaikan masalah yang diberikan. Indikator mengalami kontroversi antara lain adanya konflik kognitif, dan mengalami perbedaan pendapat yang memunculkan rasa ingin tahu. Alur pemilihan subjek seperti pada Gambar 1.

Prosedur penelitian yang dilakukan yaitu: a) tahap persiapan yang didalamnya terdapat kajian tentang berpikir kritis, masalah kontroversial dan HOTS, b) tahap pengumpulan data, c) tahap analisis data dan d) tahap penarikan kesimpulan.

Instrumen penelitian yang digunakan adalah tes dan wawancara. Tes digunakan untuk mengetahui calon guru yang mengakami kontroversial. Selanjutnya, dari calon guru yang mengalami kontroversial dilihat proses berpikir kritisnya dengan menggunakan wawancara berbasis HOTS.

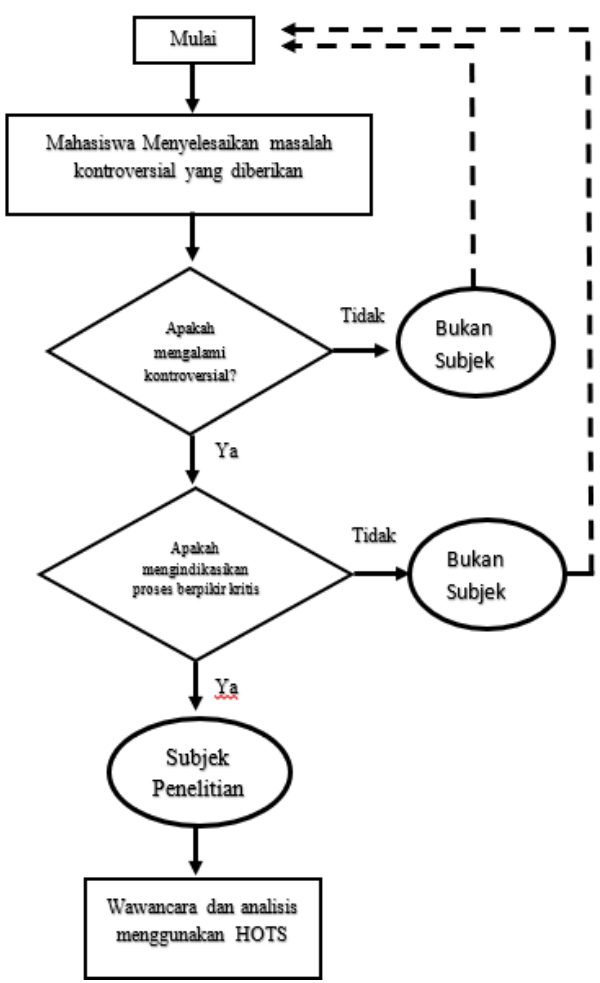

Gambar 1. Alur pemilihan subjek

Prosedur pengumpulan data yang digunakan adalah dengan memberikan masalah kontroversial kepada 150 calon guru. Proses penyusunan masalah kontroversial dimulai dengan membuat soal yang memenuhi kriteria kontroversial (adanya konflik kognitif dan adu argumen saat menyelesaikannya). Setelah itu soal dilakukan validasi ahli dan direvisi sesuai saran. Calon guru yang diberikan masalah kontrovesial adalah mahasiswa semester 6 dan 8 jurusan Pendidikan matematika. Selanjutnya calon guru yang mengalami kontroversial diwawancara untuk mengetahui proses berpikir kritisnya. Dari 150 calon guru, hanya 3 orang yang mengalami kontroversial. Hal ini dapat dilihat dari kriteria yang dimiliki yaitu: a) mengalami kontradiksi/ kontroversi, b) mengalami konflik kognitif dan c) mengalami perbedaan 
DOI: https://doi.org/10.24127/ajpm.v10i3.4082

pendapat. Ketiga calon guru tersebut diwawancara dengan menggunakan pedoman wawancara untuk mengetahui proses berpikir kritisnya menggunakan High Order Thinking Skills.

Proses berpikir kritis yang digunakan dalam penelitian ini adalah hasil kajian dari penelitian Facione
(2016) dan Ennis (2015) serta dikaitkan dengan hasil studi pendahuluan sehingga diperoleh lima aspek yaitu identifying, connecting, applying, argumentation dan clarifying.

Pedoman wawancara berdasarkan HOTS dapat dilihat pada Tabel 1.

Tabel 1. Kisi-kisi wawancara berdasarkan HOTS

\begin{tabular}{|c|c|c|}
\hline No & Kategori & Aspek \\
\hline \multirow[t]{3}{*}{1} & Analisis & $\begin{array}{l}\text { a. Membedakan mana yang relevan dan logis serta mana yang } \\
\text { tidak }\end{array}$ \\
\hline & & b. Mengorganisir hal-hal penting dari masalah yang diberikan \\
\hline & & $\begin{array}{l}\text { c. Mengaitkan masalah yang diberikan dengan apa yang sudah } \\
\text { diketahui }\end{array}$ \\
\hline \multirow[t]{2}{*}{2} & Evaluasi & a. Melakukan pengecekan kembali \\
\hline & & $\begin{array}{l}\text { b. Membahas apa yang konsisten dan tidak dari yang sudah } \\
\text { dikerjakan }\end{array}$ \\
\hline \multirow[t]{3}{*}{3} & Mencipta & a. $\quad$ Membangkitkan hipotesis \\
\hline & & b. Merencanakan untuk menyelesaikan masalah yang diberikan \\
\hline & & c. Menghasilkan produk yang baru \\
\hline
\end{tabular}

Teknik analisis data yang digunakan adalah reduksi data, penyajian data dan penarikan kesimpulan. Pada reduksi, data terjadi pengurangan data awal sehingga hanya dipilih calon guru yang mengalami kontroversi. Penyajian data dilakukan sesuai dengan tahapan pada proses berpikir kritis dan dianalisis menggunakan HOTS.

\section{HASIL DAN PEMBAHASAN}

Berdasarkan hasil penelitian, dari 150 calon guru yang diberikan masalah kontroversial matematika, hanya ada dua calon guru yang mengalami kontroversial, selanjutnya disebut dengan subjek 1 dan subjek 2 . Kedua subjek dilakukan wawancara untuk mengetahui proses berpikir kritisnya dengan menggunakan instrumen yang bercirikan HOTS.
Gambar 1 adalah jawaban dari subjek pertama

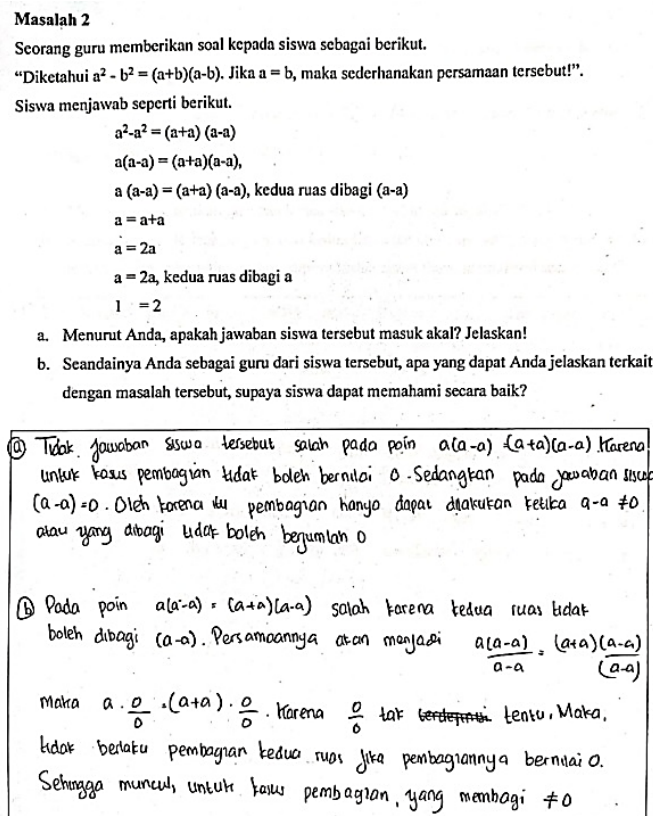

Gambar 1. Jawaban Subjek 1 
Dari Subjek 1, sudah dapat dilihat bahwa aspek berpikir kritis identifying sudah muncul, hal ini dilihat dari jawaban yang menyebutkan langkah ke tiga dari penyelesaian yaitu $a(a-a)=(a+a)(a-a)$. Untuk aspek connecting, subjek 1 sudah mengaitkan dengan materi lain yaitu menyebutkan bahwa pembagian tidak bileh bernilai 0 . Selanjutnya pada proses applying, subjek 1 menggunakan konsep yang sudah ada yaitu tidak boleh pembagian dengan 0 dalam menyelesaikan masalah kontroversial tersebut. Pada Langkah penyelesaian, subjek 1 juga menggunakan aspek argumentation yaitu menjelaskan bahwa pembagian hanya dapat dilakukan Ketika $a-a \neq 0$ atau yang dibagi tidak boleh berjumlah 0 . Pada aspek clarifying, subjek 1 sudah menjelaskan bagaimana pekerjaan yang benar menurut dia yaitu dengan menuliskan Langkah pengerjaan yang dipilih apabila dia menjelaskan kepada siswa. Untuk proses berpikir yang menggunakan HOTS subjek 1 dapat dilihat pada Tabel 2 .

Tabel 2. Analisis subjek 2 dengan HOTS

No Kategori Aspek yang muncul pada subjek 1

\begin{tabular}{|c|c|c|}
\hline \multirow[t]{3}{*}{1} & \multirow[t]{3}{*}{ Analisis } & $\begin{array}{l}\text { a. Subjek } 1 \text { dapat menyebutkan mana yang dapat dibagi } \\
\text { dengan } 0 \text { dan tidak bisa }\end{array}$ \\
\hline & & $\begin{array}{l}\text { b. Subjek } 1 \text { dapat menentukan bagian yang dapat } \\
\text { disederhanakan dan tidak bisa }\end{array}$ \\
\hline & & $\begin{array}{l}\text { c. Subjek } 1 \text { mengaitkan masalah yang diberikan dengan } \\
\text { konsep yang sudah diperoleh sebelumnya yaitu } \\
\text { pembagian dengan } 0\end{array}$ \\
\hline \multirow[t]{2}{*}{2} & \multirow[t]{2}{*}{ Evaluasi } & $\begin{array}{l}\text { Subjek } 1 \text { melakukan pengecekan kembali yaitu pada } \\
\text { saat menyebutkan Langkah mana yang belum betul dan } \\
\text { melakukan koreksi }\end{array}$ \\
\hline & & $\begin{array}{l}\text { b. Subjek } 1 \text { menyebutkan Langkah yang tidak konsisten } \\
\text { dan pada bagian yang tidak boleh dilakukan yaitu } \\
\text { langkah ke tiga dari penyelesaian yaitu } a(a-a)= \\
(a+a)(a-a) \text {. }\end{array}$ \\
\hline \multirow[t]{3}{*}{3} & \multirow[t]{3}{*}{ Mencipta } & $\begin{array}{l}\text { a. Membangkitkan hipotesis yaitu dengan cara } \\
\text { menyebutkan bahwa munculnya ketidak berlakukan } \\
\text { pada pembagian dengan kedua ruas. }\end{array}$ \\
\hline & & $\begin{array}{l}\text { b. Merencanakan untuk menyelesaikan masalah yang } \\
\text { diberikan }\end{array}$ \\
\hline & & $\begin{array}{l}\text { c. Menghasilkan produk yang baru dengan cara } \\
\text { menuliskan jawaban yang benar menurut subjek } 1\end{array}$ \\
\hline
\end{tabular}




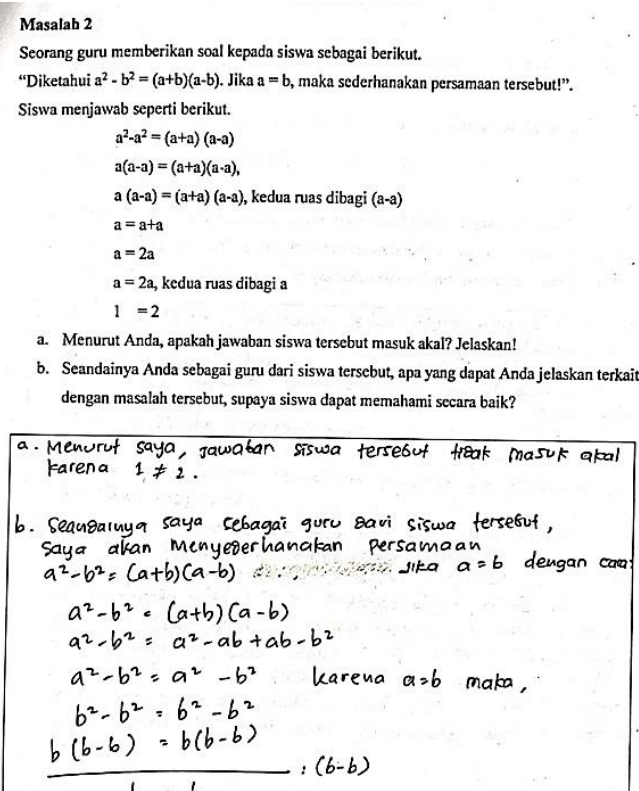

Gambar 2. Jawaban Subjek 2. sudah melakukan proses identifying yaitu menyebutkan bahwa jawaban dari siswa tidak masuk akal. Untuk proses connecting, subjek 2 belum muncul dari jawaban tetapi pada saat wawancara peneliti mendapatkan informasi bahwa subjek 2 mengaitkan masalah yang diberikan dengan konsep kontradiksi, yaitu pada saat di akhir jawaban muncul $1=2$ maka terjadi kontradiksi. Proses applying terjadi pada saat subjek 2 menggunakan konsep kontradiksi dalam menyelesaikan masalah yang diberikan. Pada aspek argumentation dan clarifying subjek 2 menyederhanakan persamaan yang diberikan dan di akhir jawaban, subjek 2 tidak menemukan kontradiksi yaitu benar bahwa $b=b$.

Berikutnya adalah jawaban dari subjek

2 disajikan pada Gambar 2. Subjek 2

Tabel 3. Analisis Subjek 2 menggunakan HOTS

\begin{tabular}{|c|c|c|}
\hline No & Kategori & Aspek yang muncul pada subjek 2 \\
\hline 1 & Analisis & $\begin{array}{l}\text { a. Subjek } 2 \text { dapat membedakan mana yang logis dan tidak pada saat } \\
\text { menemukan bahwa tidak benar bahwa } 1=2 \\
\text { b. Subjek } 2 \text { dapat Mengorganisir hal-hal penting dari masalah yang } \\
\text { diberikan dengan cara menuliskan mana yang logis dan tidak dari } \\
\text { masalah yang diberikan } \\
\text { c. Mengaitkan masalah yang diberikan dengan apa yang sudah diketahui } \\
\text { yaitu konsep kontradiksi }\end{array}$ \\
\hline 2 & Evaluasi & $\begin{array}{l}\text { a. Melakukan pengecekan Kembali dengan cara menyebutkan Langkah } \\
\text { yang belum benar. } \\
\text { b. Membahas apa yang konsisten dan tidak dari yang sudah } \\
\text { dikerjakandengan cara melakukan pengoreaksian jawaban dari } \\
\text { kontradiksi menurut subjek } 2\end{array}$ \\
\hline 3 & Mencipta & $\begin{array}{l}\text { a. Membangkitkan hipotesis yaitu tentang di akhir menyebutkan } b=b \\
\text { b. Merencanakan untuk menyelesaikan masalah yang diberikan dengan } \\
\text { cara menyelesaikan masalah yang diberikan dengan menggunakan } \\
\text { caranya sendiri }\end{array}$ \\
\hline
\end{tabular}

Tabel 3 menyajikan hasil analisis subjek 2 berdasarkan HOTS. Dari hasil jawaban calon guru dapat dilihat bahwa aspek berpikir kritis muncul dalam hasil jawaban maupun dari wawancara .

Aspek identifying calon guru bisa dilihat pada saat menuliskan apa 
yang diketahui dan ditanyakan pada soal. Seringkali aspek identifying jarang dituliskan tetapi dapat digali melalui proses wawancara (Fani et al., 2018).

Pada aspek connecting calon guru, memahami masalah yang diberikan dan mengaitkan dengan konsep yang sudah diperoleh sebelumnya (Dwi Susandi et al., 2019; Seventika et al., 2018). Aspek applying yang terjadi pada calon guru muncul pada saat menggunakan cara yang sesuai untuk menyelesaikan masalah kontroversial yang diberikan (Goldberg \& Savenije, 2018; Kello, 2016).

Untuk aspek argumentation dan clarifying berlangsung bersamaan, sehingga diperlukan wawancara untuk mengetahui informasi yang lebih mendalam. Pada argumentation, dengan adanya masalah kontroversial yang diberikan lebih memicu adu argument antara calon guru dengan peneliti (Aksu et al., 2016; Goldberg \& Savenije, 2018; Kello, 2016; Simic-Muller et al., 2015). Pada saat proses adu argumentasi, calon guru dapat menyampaikan ide dan gagasan. Baik gagasan yang benar maupun keliru tetap diberikan tanggapan oleh peneliti untuk mendapatkan informasi yang lebih baik (Bregant, 2014; Kuhn, 2010)

Analisis HOTS meliputi aspek analisis, evaluasi dan mencipta. Pada bagian analisis terjadi saat calon guru berada pada aspek identifying dan connecting. Pada aspek analisis, calon guru dapat membedakan mana yang ogis dan tidak logis (Davies \& Barnett, 2015; EL-Shaer \& Gaber, 2014). Selain itu, pada tahap analisis, terjadi proses organisir dari masalah kontroversial yang diberikan (Hilton \& Hilton, 2020; King et al., 2000; Raiyn, 2016; Widana, 2018).

Aspek evaluasi pada calon guru muncul pada aspek applying, hal ini sesuai dengan hasil penelitian Saputri et al., (2019) yang menyebutkan bahwa pada saat menggunakan cara yang sesuai untuk menyelesaikan masalah yang diberikan terjadi proses evaluasi. Pada aspek evaluasi itu sendiri terjadi proses pengecekan kembali dan mengklasifikasi mana yang konsisten dan tidak.

Mencipta adalah level tertinggi pada HOTS, tidak semua calon guru mempunyai aspek yang ada pada proses mencipta (Coffman, 2013; Widana, 2018). Menyelesaikan menggunakan caranya sendiri yang berbeda dari yang lain adalah salah satu bagian dari mencipta dalam menyelesaikan masalah (Fensham \& Bellocchi, 2013; Murtafiah et al., 2018; Narayanan \& Adithan, 2015). Proses mencipta ini terjadi pada saat aspek argumentation and clarifying selama proses diskusi.

Temuan dari penelitian ini adalah untuk proses mencipta belum muncul secara maksimal. Hal ini dikarenakan calon guru masih cenderung menggunakan cara penyelesaian yang sudah ada dan belum memaksimalkan kreatifitas dan kebaruan. Penelitian ini sudah menggunakan HOTS sebagai proses analisis data, yang sebelumnya belum pernah digunakan peneliti lain. Keterbatasan penelitian ini adalah difokuskan pada calon guru di dua Universitas di Malang, untuk penelitian berikutnya dapat dikembangkan pada calon guru di beberapa kota di Jawa timur atau lebih luas lagi yaitu di Indonesia. Penelitian ini dapat berkontribusi untuk meningkatkan proses berpikir kritis calon guru, sehingga dapat dijadikan acuan dalam menyusun instrument yang sesuai. 
DOI: https://doi.org/10.24127/ajpm.v10i3.4082

\section{KESIMPULAN DAN SARAN}

Proses berpikir dalam menyelesaikan masalah kontroversial matematika terdiri dari aspek identifying, connecting, applying, argumentation dan clarifying. Pada saat menggunakan HOTS untuk mengetahui proses berpikir kritisnya diperoleh kesimpulan bahwa tahap analisis terjadi pada saat calon guru identifying dan connecting. Untuk aspek evaluasi terjadi pada saat calon guru melakukan proses applying. Untuk aspek mencipta, terjadi pada saat calon guru menggunakan argumentation and clarifying dalam menyelesaikan masalah yang diberikan.

Saran untuk penelitian berikutnya adalah menggunakan teori lain untuk melihat proses berpikir calon guru dalam menyelesaikan masalah kontroversial. Salah satu teori yang bisa digunakan adalah teori APOS.

\section{DAFTAR PUSTAKA}

Ab Kadir, M. A. (2017). What Teacher Knowledge Matters in Effectively Developing Critical Thinkers in the 21 st Century Curriculum? Thinking Skills and Creativity. https://doi.org/10.1016/j.tsc.2016.1 0.011

Aksu, Z., Ozkaya, M., Gedik, S. D., \& Konyalioglu, A. C. (2016). Mathematics Self-efficacy and Mistake-handling Learning as Predictors of Mathematics Anxiety. Journal of Education and Training Studies, 4(8). https://doi.org/10.11114/jets.v4i8.1 533

Arifin, S., Setyosari, P., Sa'dijah, C., \& Kuswandi, D. (2019). Increasing Critical Thinking and Student Retention: A Learning Model Approach. International Journal of Research \& Review.
As'ari, A. R., Mahmudi, A., \& Nuerlaelah, E. (2017). Our prospective mathematic teachers are not critical thinkers yet. Journal on Mathematics Education. https://doi.org/10.22342/jme.8.2.39 61.145-156

Ayvaz, Ü., Gündüz, N., Durmuş, S., \& Dündar, S. (2016). Subtraction Performances of Primary School Prospective Mathematics Teachers Having Different Cognitive Styles. Universal Journal of Educational Research.

https://doi.org/10.13189/ujer.2016. 041321

Basri, H., Purwanto, As'ari, A. R., \& Sisworo. (2019). Investigating critical thinking skill of junior high school in solving mathematical problem. International Journal of Instruction.

https://doi.org/10.29333/iji.2019.1 $2345 \mathrm{a}$

Bregant, J. (2014). Critical thinking in education: why to avoid logical fallacies? Philosophy of Mind and Cognitive Modelling in Education, 61, 18-27.

Coffman, D. M. (2013). Thinking about Thinking: An Exploration of Preservice Teachers' Views about Higher Order Thinking Skills. Phd Thesis.

Davies, M., \& Barnett, R. (2015). The palgrave handbook of critical thinking in higher education. In The Palgrave Handbook of Critical Thinking in Higher Education. https://doi.org/10.1057/978113737 8057

Dwi Susandi, A., Sa'Dijah, C., Rahman As'Ari, A., \& Susiswo. (2019). Students' critical ability of mathematics based on cognitive styles. Journal of Physics: Conference Series. 
https://doi.org/10.1088/17426596/1315/1/012018

EL-Shaer, A., \& Gaber, H. (2014). Impact of problem-based learning on student critical thinking dispositions, knowledge acquisition and retention. Journal of Education and Practice. https://doi.org/10.1021/ol1022257

Ennis, R. H. (2015). Critical Thinking: A Streamlined Conception. In The Palgrave Handbook of Critical Thinking in Higher Education. https://doi.org/10.1007/978-1-13737805-7_2

Facione, P. A. (2016). Critical Thinking: What It Is and Why It Counts Peter A. Facione The. Molecular Imaging and Biology. https://doi.org/10.1007/s11307016-1031-0

Fani, E. T. R., Baiduri, B., \& Rosyadi, A. A. P. (2018). Analysis Of Students' Critical Thinking and Independence of Learning Through Problem-Based Learning. Mathematics Education Journal. https://doi.org/10.22219/mej.v2i2.6 500

Fensham, P. J., \& Bellocchi, A. (2013). Higher order thinking in chemistry curriculum and its assessment. Thinking Skills and Creativity. https://doi.org/10.1016/j.tsc.2013.0 6.003

Goldberg, T., \& Savenije, G. M. (2018). Teaching Controversial Historical Issues. In The Wiley International Handbook of History Teaching and Learning (pp. 503-526). https://doi.org/10.1002/978111910 0812.ch19

Hariyani, S., Yuwono, I., Sa 'dijah, C., \& Rahardjo, S. (2016). Math Problem Solving Phases on Thinking Outside The Box. IOSR Journal of Research \& Method in
Education Ver. III. https://doi.org/10.9790/73880604034348

Hilton, A., \& Hilton, G. (2020). Higher order thinking. In Teaching Middle Years.

https://doi.org/10.4324/978100311 7780-16

Kello, K. (2016). Sensitive and controversial issues in the classroom: Teaching history in a divided society. In Teachers and Teaching: Theory and Practice. https://doi.org/10.1080/13540602.2 015.1023027

King, F., Goodson, L., \& Rohani, F. (2000). Higher Order Thinking Skills Lower Order Thinking Skills. In Publication of the Educational Services Program, now known as the Center for Advancement of Learning and Assessment. Obtido de: www.cala.fsu.edu.

Kuhn, D. (2010). Thinking as argument. In Critical Readings on Piaget. https://doi.org/10.4324/978020343 5854_chapter_7

Mueller, M., \& Yankelewitz, D. (2014). Fallacious Argumentation in Student Reasoning: Are There Benefits? European Journal of Science and Mathematics Education.

Murtafiah, W., Sa'dijah, C., Candra, T. D., Susiswo, \& As'ari, A. R. (2018). Exploring the explanation of pre-service teacher in mathematics teaching practice. Journal on Mathematics Education, 9(2), 259-270. https://doi.org/10.22342/jme.9.2.53 88.259-270

Narayanan, S., \& Adithan, M. (2015). Analysis Of Question Papers In Engineering Courses With Respect To Hots (Higher Order Thinking 
DOI: https://doi.org/10.24127/ajpm.v10i3.4082

Skills). American Journal of Engineering Education (AJEE). https://doi.org/10.19030/ajee.v6i1. 9247

Nugroho, P. B., Nusantara, T., As'ari, A. R., Sisworo, Hidayanto, E., \& Susiswo. (2018). Critical thinking disposition: Students skeptic in dealing with ill-logical mathematics problem. International Journal of Instruction.

https://doi.org/10.12973/iji.2018.1 $1343 \mathrm{a}$

Raiyn, J. (2016). The Role of Visual Learning in Improving Students' High-Order Thinking Skills. Journal of Education and Practice. Rasiman. (2015). Leveling of critical thinking abilities of students of mathematics education in mathematical problem solving. Journal on Mathematics Education.

https://doi.org/10.22342/jme.6.1.19 41.40-52

Rosyadi, A. A. P. (2021). ANALISIS

BERPIKIR KRITIS

MAHASISWA DALAM

MENYELESAIKAN MASALAH KONTROVERSIAL

MATEMATIKA. EDU-MAT:

Jurnal Pendidikan Matematika, 9(1).

https://doi.org/10.20527/edumat.v9 i1 .9988

Saputri, A. C., Sajidan, Rinanto, Y., Afandi, \& Prasetyanti, N. M. (2019). Improving students' critical thinking skills in cellmetabolism learning using Stimulating Higher Order Thinking Skills model. International Journal of Instruction. https://doi.org/10.29333/iji.2019.1 $2122 \mathrm{a}$

Serin, O. (2013). The Critical Thinking Skills of Teacher Candidates
Turkish Republic of Northern Cyprus Sampling. Eurasian Journal of Educational Research. https://doi.org/10.14689/ejer.2013. 53.13

Seventika, S. Y., Sukestiyarno, Y. L., \& Mariani, S. (2018). Critical thinking analysis based on Facione (2015) - Angelo (1995) logical mathematics material of vocational high school (VHS). Journal of Physics: Conference Series. https://doi.org/10.1088/17426596/983/1/012067

Simic-Muller, K., Fernandes, A., \& Felton-Koestler, M. D. (2015). "I just wouldn't want to get as deep into it": Preservice teachers' beliefs about the role of controversial topics in mathematics education. Journal of Urban Mathematics Education.

Smith, T. E., Rama, P. S., \& Helms, J. R. (2018). Teaching critical thinking in a GE class: A flipped model. Thinking Skills and Creativity, 28, 73-83. https://doi.org/10.1016/j.tsc.2018.0 2.010

Susandi, A. D., Sa'dijah, C., Asari, A. R., \& Susiswo, S. (2018). Error Analysis on Prospective Teacher in Solving the Problem of Critical Thinking Mathematics with Apos Theory. https://doi.org/10.2991/icomse17.2018 .13

Widana, I. W. (2018). Higher Order Thinking Skills Assessment towards Critical Thinking on Mathematics Lesson. International Journal of Social Sciences and Humanities (IJSSH). https://doi.org/10.29332/ijssh.v2n1 .74 